\title{
Valheiden levitys ja median tilanne Tšekin tasavallassa
}

Tšekin tasavallan sijoitus on pudonnut Toimittajat ilman rajoja -järjestön julkaisemassa lehdistönvapausindeksissä sijalle 40. Pudotukseen on monia syitä: oligarkit ja poliitikot ovat ostaneet mediataloja, korkean tason poliitikot ovat hyökänneet journalisteja vastaan ja levittäneet disinformaatiota, ja lisäksi kansalaisten ulottuvilla on venäläisiä valeuutissivustoja. Kun hallitus on toistaiseksi tehnyt vähän tilanteen helpottamiseksi, ihmiset ovat luoneet erilaisia vapaaehtoisorganisaatioita disinformaation vastustamiseksi.

Oligarkkien kiinnostus mediaomistukseen omien intressiensä ajamiseksi alkoi jo vuonna 2008. Vuonna 2013 pääministeri Andrej Babiš osti Tšekin suurimman mediayhtiön MAFRAn, joka julkaisee esimerkiksi maan luetuimpiin kuuluvia $M F$ DNES ja Metro-lehtiä. Babiš on syytteessä EU-rahoituksen väärinkäytöksistä, ja monet kansalaiset ja journalistit ovat valittaneet tämän vaikuttavan näiden mediatalojen uutisiin. Muun muassa tästä on kummunnut Babišia vastaan suunnattuja mielenosoituksia, jotka ovat suurimpia sitten kommunistien vallan päättymisen.

Andrej Babiš ei kuitenkaan ole ainoa korkean tason poliitikko, jonka toimet vaikuttavat lehdistönvapauden heikkenemiseen. Tšekin presidentti Miloš Zeman on toistuvasti hyökännyt journalisteja vastaan. Vuonna 2017 hän kerskui lehdistötilaisuudessa Kalašnikovin näköiskappaleella, jossa luki "Toimittajille”. Ennen vuoden 2018 presidentinvaaleja Zemanin kampanjassa työskennellyt henkilö hyökkäsi verbaalisesti ja fyysisesti Zemanin pääkonttorilta raportoivia journalisteja vastaan. Presidentti kritisoi Tšekin julkisen palvelun televisiota ja radiota päivittäin ja näin heikentää ihmisten luottamusta mediaan.

Jotkut poliitikoista jopa levittävät itse valheellista tietoa. Esimerkiksi äärioikeistolaisen SPD-puolueen johtaja Tomio Okamura julkaisi toukokuussa 2019 puoluelehden Na vlastni oči (Omin silmin), joka oli täynnä manipulaatiota ja valheita ja jonka tarkoituksena oli vaikuttaa ihmisten näkemyksiin ennen Euroopan unionin parlamenttivaaleja. SPD:1lä on 22 paikkaa Tšekin parlamentin edustajainhuoneessa. EU-vaalien alla julkaistu lehti väitti esimerkiksi Tšekin joutuvan maksamaan EU:lle paljon enemmän kuin maa saa takaisin (vaikka on yksi suurimmista EU:n hyötyjistä), tai että EU haluaa kieltää veitsien kuljettamisen mukana sekä käyrät banaanit. Okamura levittää myös euroskeptisismiä, muukalaisvihamielisyyttä ja muita pelkoja Facebook-sivunsa videoblogeissa. Pelko voi vaikuttaa mielipiteiden lisäksi tekoihin. Vuonna 2018 SPD-äärioikeistopuoluetta tukeva ikäihminen Jaromír Balda sai 
Tšekin tasavallan ensimmäisen terrorismia koskevan tuomion kaadettuaan junaraiteille kaksi puuta, jotka aiheuttivat junaonnettomuuksia. Hän oli jättänyt rikospaikalle lentolehtisiä joissa luki "Allahu akbar", yrittäen näin vierittää syyn islamisteille. Vaikka SPD-puolue irtautui hänen teostaan, useiden asiantuntijoiden mukaan Balda sai innoituksen SPD:n levittämästä vihapuheesta. Disinformaation kohderyhmänä ovat usein ikäihmiset. Vuoden 2018 presidentinvaalikampanjan aikana iäkkäille ihmisille lähetettiin sähköpostilla ketjukirjeitä, joissa syytettiin istuvan presidentin Miloš Zemanin kilpailijaa Jiř́ Drahošia pedofiliasta, sponsorituen saamisesta hyväntekijänä tunnetulta miljardööriltä George Sorosilta (jota monet tšekkiläiset pitävät epäluotettavana) tai siitä, että Drahoš haluaa avata rajat maahanmuuttajille. Joidenkin arvioiden mukaan Zeman ei olisi pystynyt voittamaan vaaleja ilman sähköpostikampanjaa.

Suuri osa tšekkiläisiltä verkkosivustoilta löytyvästä disinformaatiosta on peräisin Venäjältä. Vierailluimmat väärää tietoa levittävät sivustot ovat Sputnik ja Aeronet, joista ensimmäinen on venäläinen, mutta sillä on myös tšekin kielistä toimintaa ja toisella on selviä Venäjä-yhteyksiä. Ihmiset seuraavat myös Facebook-ryhmiä, joiden vetäjien verkostoja on tekaistujen profiilien vuoksi vaikea jäljittää. Tällaiset ryhmät ja vaihtoehtotietoa esittävät Internet-sivustot vähentävät luottamusta perinteiseen mediaan, levittävät euroskeptisismiä, pelkoa, ulkomaalaisvihaa ja siirtävät kansan tukea maantieteellisesti lännestä itään.

Tšekin tasavallasta puuttuu tasokas mediaopetus, koska maassa ei ole siitä perinteitä yli 40 vuoden kommunistivallan vuoksi. Hallitus on tehnyt hyvin vähän valeuutisten torjumiseksi verrattuna Suomeen, jossa on etsitty digilukutaidon keinoja ja järjestetty työpajoja viranhaltijoille. Silti monet kansalaisjärjestöt taistelevat näiden asioiden hyväksi. Esimerkiksi Elf Group monitoroi sähköpostissa leviäviä ketjukirjeitä ja väärennettyjä sosiaalisen median tilejä, Demagog tekee poliitikkoihin ja puolueisiin liittyvää faktantarkistusta ja journalistinen Manipulators-verkkosivusto oikaisee disinformaatiota. Ihmiset alkavat hitaasti oppia ajattelemaan kriittisesti eivätkä tartu niin helposti valeuutisten monitahoisiin syötteihin. Tšekin tasavalta tarvitsisi valtion tason systemaattisia toimia, mutta toistaiseksi sen täytyy taistella käytettävissä olevin keinoin.

Englannista kääntänyt Katja Lehtisaari.

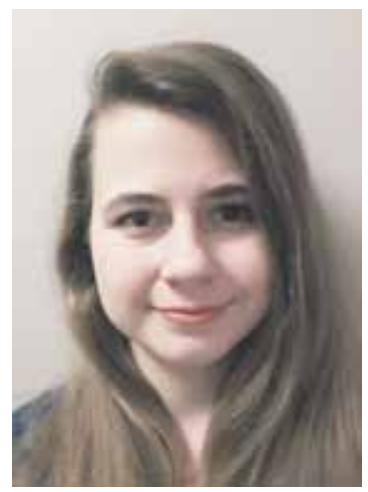

Barbora Novotná

Kirjoittaja on journalistiikan opiskelija Kaarlen yliopistossa Prahassa. Joulukuussa 2019 hän vietti kaksi viikkoa Suomessa keskustellen asiantuntijoiden ja journalistien kanssa disinformaatiosta ja työstää nyt käytyjen keskustelujen pohjalta journalisteille tarkoitettua ohjekirjaa. 